\title{
Preparation and evaluation of a biomimetic scaffold with porosity gradients in vitro
}

\author{
QIANBIN WANG ${ }^{1,2}$, QIGUANG WANG $^{2}$ and CHANGXIU WAN ${ }^{2}$ \\ ${ }^{1}$ School of Chemistry and Environment, Beihang University, Beijing 100191, P.R. China \\ ${ }^{2}$ College of Polymer Science and Engineering, Sichuan University, Chengdu 610065, P.R. China \\ Manuscript received on December 21, 2010; accepted for publication on May 30, 2011
}

\begin{abstract}
A novel biodegradable scaffold based on mimetic a natural bone tissue morphology with a porosity gradient structure was prepared in this paper. The result of surface morphology indicated that a graded porous structure was formed in the fabricated scaffold, where the dense layer $(0 \%)$ was connected with the most porous layer $(60 \%)$ by a middling porous layer $(30 \%)$. To evaluate the degradability, graded porous scaffolds compared with homogeneous scaffolds were placed into a Tris-HCl buffer solution $(\mathrm{pH}=7.4)$ for 28 days. It was found that both scaffolds presented the same degradation trend, and the graded porous structure did not change the original degradability of the scaffold. Moreover, the compressive strength of the graded porous scaffold was better than that of conventional homogeneous scaffold with the increase of degradation time, and the graded porous structure can enhanced the mechanical property of the scaffold. These findings suggest that this biodegradable and porosity-graded scaffold may be a new promising scaffold for loaded bone implant.
\end{abstract}

Key words: biodegradable, biomimetic, graded porous scaffold, compressive strength.

\section{INTRODUCTION}

Bone has a functionally graded structure from the surface cortical bone towards the inner cancellous bone (Fig. 1a). Therefore, the biomedical implant should be designed with a porosity gradient simulating as much as possible the bimodal structure of the bone (cortical and cancellous) (Fig. 1a) (Hing et al. 1999, Castillo et al. 2003). The production of implant material with graded porosity has been attempted with hydroxyapatite (HA) by Tampieri et al., and they found that the high-porosity portion allows a good and fast bone ingrowth and the

Correspondence to: Changxiu Wan

E-mail:wancx@scu.edu.cn low-porosity side can withstand early physiologic mechanical stress (Tampieri et al. 2001). Becker and Pompe reported that functionally graded material could give the implant a suitable strength to withstand the physiological loading, and that the graded porosity structure can optimize the material's response to external loading; a similar feature might prove favorable to an artificial bone implant (Becker and Bolton 1997, Pompe et al. 2003). Many studies had demonstrated that graded porous materials provide the advantage to engineer material with specific structural, morphological and mechanical properties (Tampieri et al. 2001, Pompe et al. 2003, Castillo et al. 2003). 


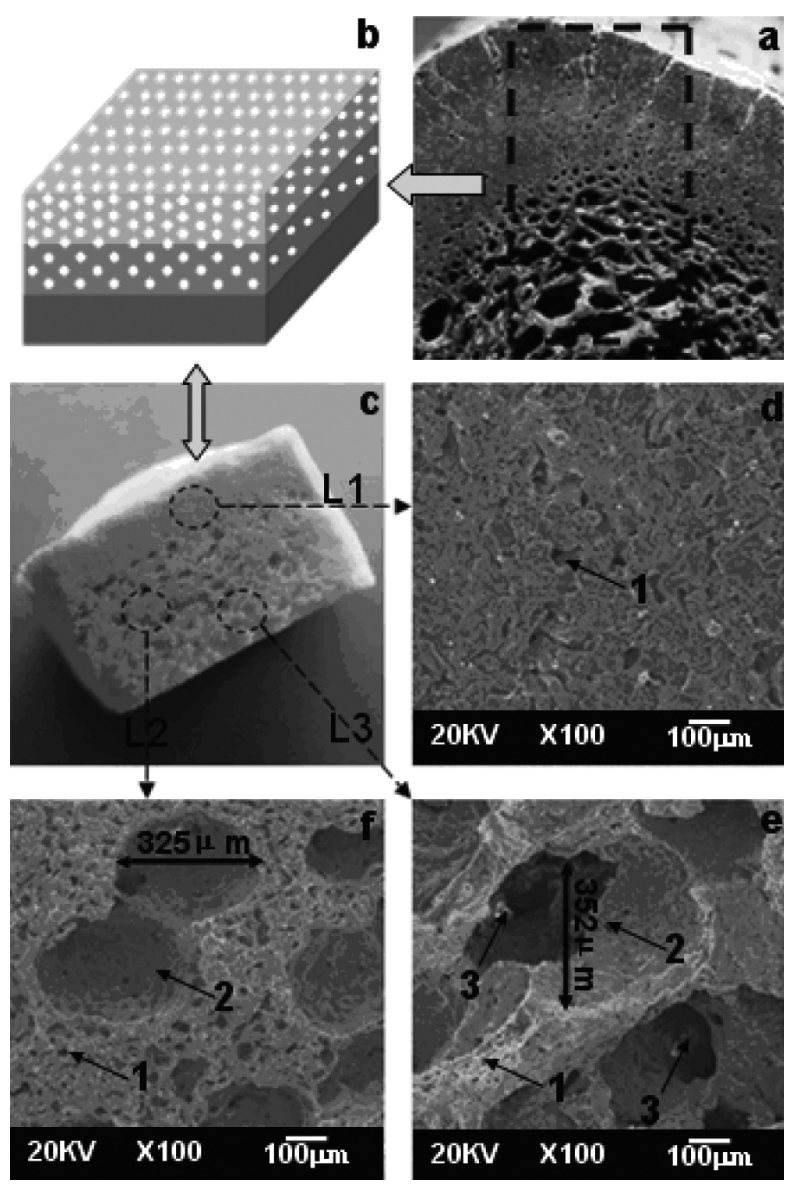

Fig. 1 - The porosity-graded calcium polyphosphate scaffold prepared in this paper. (a) the functionally graded structure of a natural bone, (b) the schematic representation of an artificial scaffold, (c) the photograph of the scaffold, (d)-(f) SEM pictures of different layers.

Degradability is one of the most concerned properties in the research field of bone repair materials because it is crucial for bone induction, conduction, metabolism and longevity on implants. According to the research made by Hench LL, the degradation speed of HA is generally slow, which is incompatible with bone growth (Hench 1998). Implants made of alloy or ultra-high molecular weight polyethylene (UHMWPE) materials are not degraded either in the body and need to be removed again (Lieberman and Friedlander 2005). The uncontrollable degradability of these biomaterials limited them to be used in bone implants. Calcium polyphosphate (CPP), a new promising biomaterial for bone tissue engineering, has been fast developed since its rediscovery and use in bone regeneration (Pilliar et al. 2001, Grynpas et al. 2002, El Sayegh et al. 2002, Waldman et al. 2002). CPP has drawn many researchers' attention not only for its outstanding biocompatibility, but also for its controllable degradability, excellent mechanical property, and so on (Park et al. 2004, Yang et al. 2004, Ding et al. 2008, Chen et al. 2008, Wang et al. 2009). All these studies indicated that CPP is an ideal bioceramic with excellent osteoinduction and osteoconduction for bone substitute.

In this paper; we describe a novel calcium polyphosphate bioceramic scaffold with a graded pore structure similar to the bimodal structure of cortical and cancellous bones. Porosity, pore size, degradability and compressive strength of the scaffold were investigated in vitro. The objective of this paper is to produce a controllable biodegradable scaffold with graded and interconnected porosity to improve its mechanical properties for a possible use as loaded bone implants.

\section{MATERIALS AND METHODS}

The preparation of CPP powder has been described in details by Qiu (Qiu et al. 2006). Briefly, calcium phosphate monobasic monohydrate powder was placed into a $100 \mathrm{~cm}^{3}$ crucible and sintered at $500^{\circ} \mathrm{C}$ for $10 \mathrm{~h}$ to drive off the crystalline water. Then the powder was melted at $1200^{\circ} \mathrm{C}$ for $1 \mathrm{~h}$ to further polymerize. The molten CPP was quenched in distilled water to obtain CPP amorphous frits. The frits were milled and screened to yield powders in a size range of $48-75 \mu \mathrm{m}$.

The porosity-graded calcium polyphosphate (PGCPP) scaffold was designed to be composed of three functional regions as shown in Figure $1 \mathrm{~b}$. The high porosity region $(60 \%)$ and denser region $(0 \%)$ were connected by a layer with intermediate 
porosity $(30 \%)$, while the homogeneous calcium polyphosphate (HCPP) scaffold was designed to be homogeneous and monolithic. CPP powder and stearic acid were mixed with paste to fill into a rectangular stainless-steel mold layer by layer. Then samples were pressed by a constant compressive stress between 0.9 to $1 \mathrm{MPa}$. After drying, these samples were sintered at $800^{\circ} \mathrm{C}$ for $3 \mathrm{~h}$ and then cooled naturally to room temperature in furnace for benefiting crystal growth.

The macrostructure of PG-CPP samples was observed using a digital camera. A JSM-5900LV scanning electron microscopy (SEM) was used to evaluate the graded porosity structure of the samples, and a X'Pert Pro MPD X-ray diffractometer (Philips, Netherlands) was performed to identify the crystalline phases of the samples.

The degradation testing was carried out at $37^{\circ} \mathrm{C}$ for $1,2,3,5,7,10,13,16,20,24$ and 28 days in a Tris- $\mathrm{HCl}$ buffer solution ( $\mathrm{pH}=7.4)$, according to ISO 10993-14, using triplicate samples. The quantitative determination of ions released into the testing solution was preformed using two different techniques. Calcium ions were measured by EDTA titration (Dion et al. 2005), whereas the total orthophosphate ion concentration in the supernatant was measured by ultraviolet spectroscopy using the molybdenum blue method (UV-754, China) (Fiske and Subbarow 1925).

For the compressive strength measurements, the samples were immersed in a Tris- $\mathrm{HCl}$ buffer solution at $37^{\circ} \mathrm{C}$ for 0,14 and 28 days, then taken out and dried at $80^{\circ} \mathrm{C}$ for $24 \mathrm{~h}$. The samples were loaded with a crosshead speed of $1 \mathrm{~mm} . \mathrm{min}-1$ using a screw-driven load frame (Instron 4302, American). The stress and strain responses were monitored. Five samples in each group were tested to obtain average values and standard deviations.

The results were presented as arithmetic means \pm standard deviation. The analysis of the results was carried out using Student's t-test, with a significance level of $p<0.05$.

\section{RESULTS AND DISCUSSION}

Thegraded porous structure of calcium polyphosphate scaffold is presented in Figure 1. Figure 1c shows the cross-section of the porosity-graded scaffold with three different porosity layers: L1, L2 and L3. The surface of the sample becomes coarse and more porous from L1 to L3. L1 (Fig. 1d) mimicked the human cortical bone (density), while L3 simulated the human cancellous bone (porosity). L3 (Fig. 1e) exhibited a three-dimensionally interconnected pore structure and connected to the rest of the neighbour pores by throats (identified by number 3 ), and the diameter of the pores was all about 200-400 $\mu \mathrm{m}$ (identified by number 2). When implanted into the body, the highly interconnected macro-porous network of the scaffold allows not only cell growth, but also the flow transport of nutrients and metabolic waste. L2 (Fig. 1f) was used to connect L1 and L3 and avoided visible layer-layer interface. As shown in Figure 1c, the contact among various microporous layers is good. From L3 to L1, the scaffold becomes denser. These results indicate that a graded porous structure is formed in the CPP scaffold.

The porosity of both scaffolds was measured and presented in Table I. It was found no significant difference between these two groups. The homogeneous scaffold and the graded porous scaffold exhibited $(32.73 \pm 0.71) \%$ and $(32.87 \pm$ $0.82) \%$ porosity, respectively. It was noted that the percent of porosity was higher than the theoretical result, which indicated that the sintering procedure would cause some pores as presented in the SEM picture. As shown in Figure 1d-f, there were some micro-pores (identified by number 1) around the macro-pore (identified by number 2). We have been realized that both the macroscopic and the microscopic pores are important morphological properties of a biomaterial scaffold for bone regeneration (Yoshikawa and Myoui 2005). Typically, the macro-pores $(\geq 100 \mu \mathrm{m})$ produced by porogens allow the scaffold colonization by osteoblasts, while 
the micro-pores $(\leq 50 \mu \mathrm{m})$ formed from sintering promote scaffold vascularization (nutrients supplying for cells, waste products removal).

TABLE I

Porosity of the both types of CPP.

\begin{tabular}{c|c|c}
\hline Samples & $\begin{array}{c}\text { Theoretical porosity } \\
(\%)\end{array}$ & $\begin{array}{c}\text { Measurement porosity } \\
(\%)\end{array}$ \\
\hline H-CPP & 25 & $32.73 \pm 0.71$ \\
PG-CPP & 25 & $32.87 \pm 0.82$ \\
\hline
\end{tabular}

Porosity is defined as the percentage of void space in a scaffold, and it plays a critical role in bioscaffold design in vitro and bone formation in vivo (Athanasou 1996). It has been demonstrated that the bio-scaffolds should exhibit pore content and size. The most porous structures are more likely to offer good conditions for cell growth and flow transport of nutrients and metabolic waste because of their greater specific surface area (Sous et al. 1998). In this article we designed a biomimetic scaffold with a porosity-graded structure. The most porosity layer simulated the cancellous bone and may provide a better condition for cell ingrown, while the density layer may meet the mechanical need when implanted in body.

The design of human bone, how it demonstrates change from a dense stiff external structure of the cortical bone to the light and porous cancellous bone on the interior surface, is a perfect example of porosity-graded material (Fig. 1a). This structure has been used in scaffolds for bone implant by many researchers (Becker and Bolton 1997, Castillo et al. 2003, Pompe et al. 2003), and they found that the porosity-graded structure can optimize the material's response to external loading; a similar feature might prove favorable to an artificial bone implant.

Bio-scaffold requires controllable degradability and a 3D structure. As shown in Figure 2, the concentrations of orthophosphate and calcium ions during the immersion period for both scaffolds were increased. Two different types of scaffolds presented the same degradation trend and velocity during the degradation. The weight loss of H-CPP and PG-CPP scaffolds were $(10.1 \pm 0.03) \%$ and $(10.4 \pm 0.02) \%$ after 28 days of degradation in a Tris- $\mathrm{HCl}$ buffer solution, respectively. Combined with Table I, the results indicated that the graded porous structure did not change the degradability of CPP.

Hench and Polak (2002) postulated the definition of the third generation of biomaterials, both bioactive and biodegradable materials (Hench and Polak 2002). It is known to us that degradability is a concerned property for implanting biomaterials because it is crucial for bone induction, conduction, metabolism and longevity on implants. Nowadays calcium phosphate-based bioceramics are the most common biomaterials for bone implant. However, the degradability of HA and $\beta$-TCP was uncontrollable, which limited them to apply in bone regeneration. Very recently, $\beta$-CPP, a novel biomaterial, has drawn many researchers' attention because of its controllable degradation, biocompatibility and osteoconduction (Park et al. 2004, Yang et al. 2004, Ding et al. 2008, Chen et al. 2008, Wang et al. 2009). As shown in Figure $2 \mathrm{a}$, the three char $\neg$ acteristic peaks of XRD pattern indicated that the CPP prepared in this paper was beta crystalline phase. As a novel biomaterial, calcium polyphosphate has been wildly developed in recent years partly due to its controllable degradability. The crystal structure (Qiu et al. 2005), sintering time and temperature (Wang et al. 2010a, b), polymerization degree (Ding et al. 2008, Qiu et al. 2005), porosity (Wang et al. 2011), ion doped (Song et al. 2008) and degradation media (Wang et al. 2009) can affect the degradation rate of the CPP bioceramic.

The mean compressive strength for the samples aged in a Tris- $\mathrm{HCl}$ buffer solution $(\mathrm{pH}$ 7.4) for 0,14 and 28 days is presented in Figure 3a. The compressive strength of both types of scaffolds 

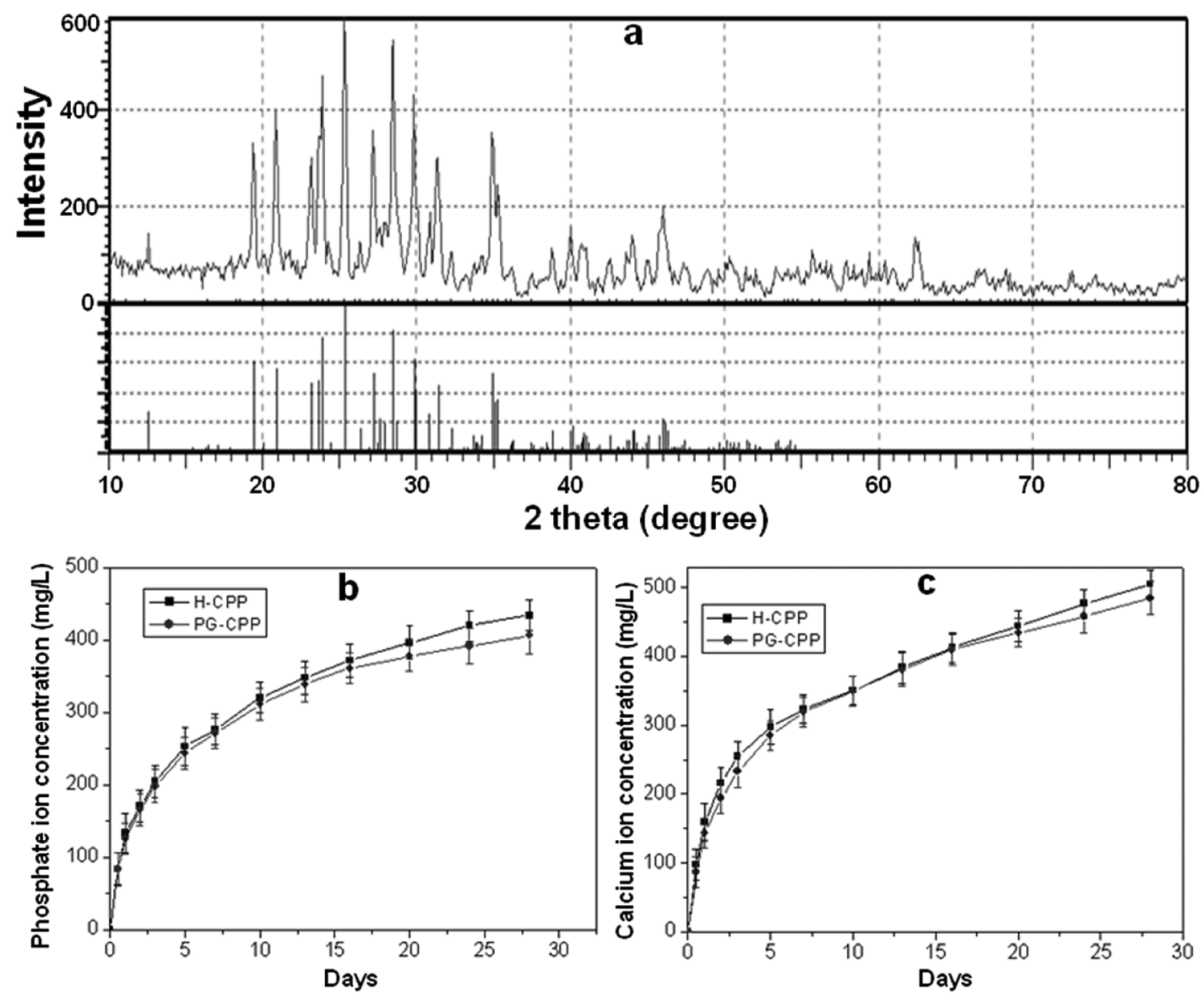

Fig. 2 - (a) XRD pattern of calcium polyphosphate obtained in this work, and the $\mathrm{PO}_{4}^{3-}$ ion (b) and $\mathrm{Ca}^{2+}$ ion (c) concentration during the degradation in the Tris-HCl buffer solution ( $\mathrm{pH} 7.4)$.
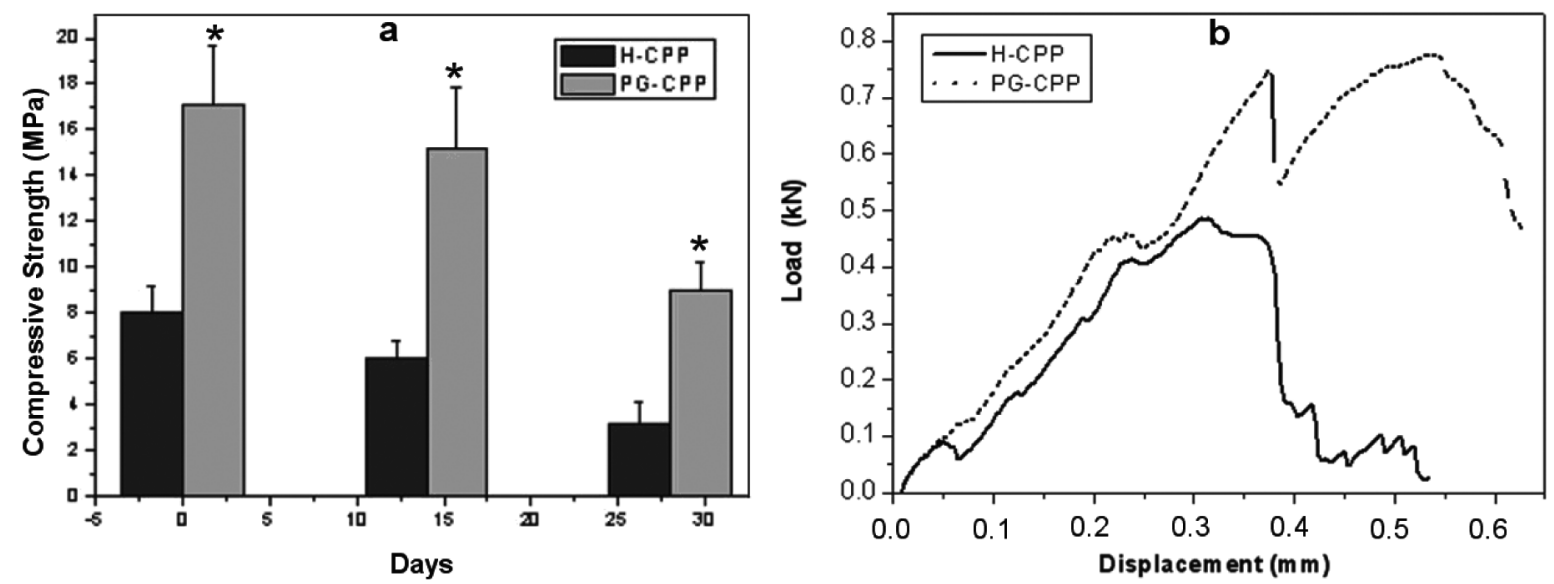

Fig. 3 - The mechanical property of H-CPP and PG-CPP: (a) compressive strength of both types of scaffolds before and after degradation. Asterisk $\left(^{*}\right)$ means that the compressive strength of $\mathrm{PG}-\mathrm{CPP}$ has a statistically significant difference compared with the $\mathrm{H}-\mathrm{CPP}, \mathrm{P}<0.05, \mathrm{n}=5$; (b) the load-displacement curves of both types of scaffolds. 

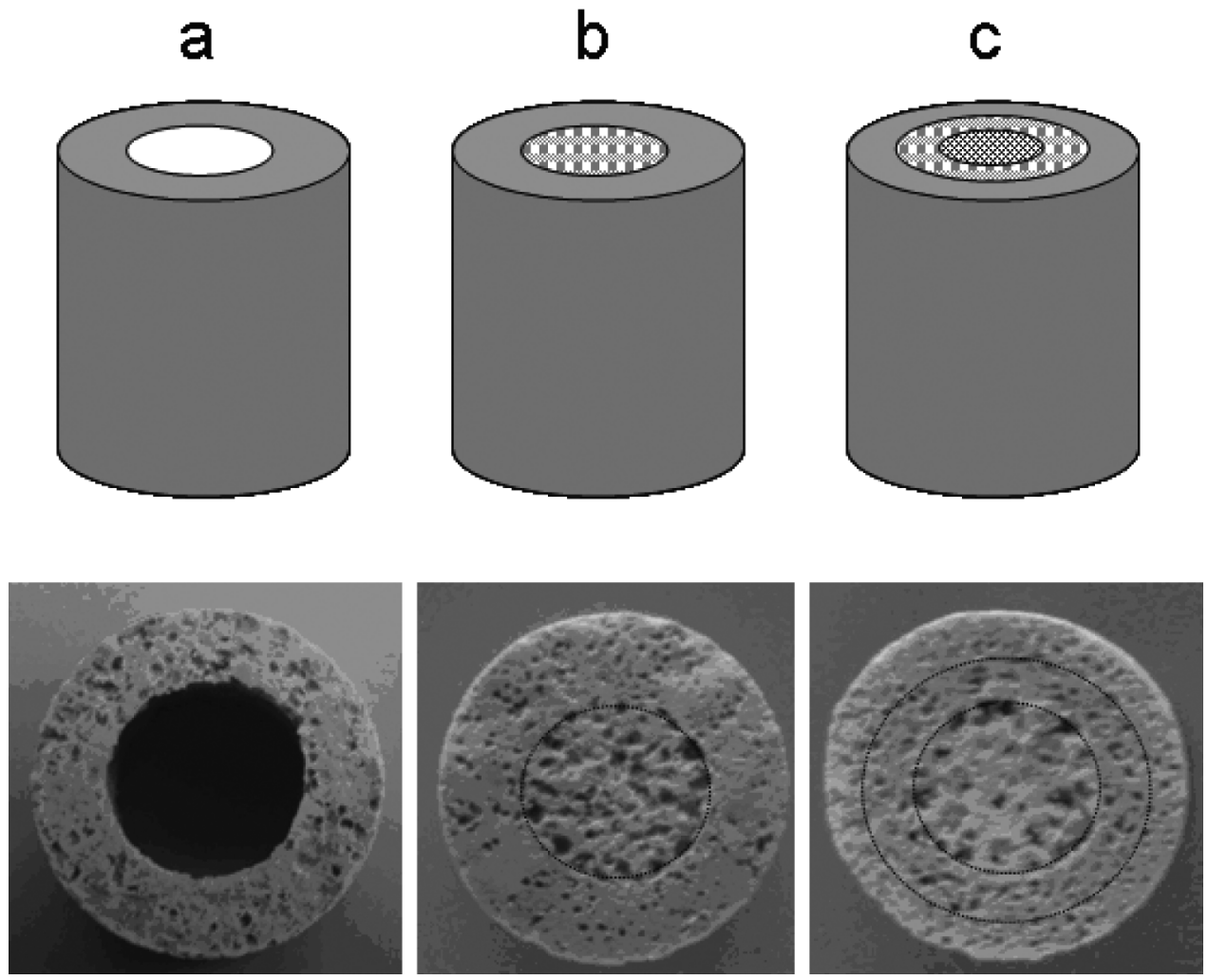

Fig. 4 - Schematic diagrams and photographs of scaffolds with a radial gradient porosity: (a) porous scaffold with a hollow center, (b) two graded porous layers, and (c) three graded porous layers.

changes significantly $(p<0.05)$ within the degradation test period. For example, as the scaffold immersion in solution increased from 0 to 14 days, the compressive strength of H-CPP scaffold decreased $53 \%$, but the PG-CPP scaffold only decreased 17\%. The compressive strength for H-CPP scaffolds decreased from 5.16 MPa to $4.48 \mathrm{MPa}$, while the compressive strength of PG-CPP scaffolds decreased from 12.57 MPa to 8.98 MPa from 14 to 28 days.

The compressive strength of PG-CPP scaffolds was better than H-CPP scaffolds, which was significant $(\mathrm{p}<0.05)$ at each time point. It was noted that, after 28 days of degradation, the compressive strength of PG-CPP scaffolds ws still $8.98 \mathrm{MPa}$, which was even greater than that of primary H-CPP. The result indicated that the scaffold with a porosity-graded structure has a much better mechanical property.
Figure $3 b$ shows the load-displacement curves of the porosity-graded scaffold and the conventional homogeneous scaffold, respectively. It can be seen that the porosity-graded scaffold exhibits a non-brittle failure, while the conventional homogeneous scaffold fractures catastrophically. For the porosity-graded scaffold, after the first load drop, the load-bearing ability of the testing bar still retains over $75 \%$ of the peak load. Until totally fractured, the porosity-graded scaffold gives a prolonged deflection besides the elastic deformation. This shows that the porosity-graded scaffold exhibits a different fracture behavior from that of the conventional homogeneous scaffold. Hence, it may be inferred that the mechanical properties of the porosity-graded scaffold can be substantially improved by a graded porous structure. 
Biomechanics is one important function of bone. So, the design of biomaterial scaffold must have a reasonable mechanical strength. However, the degradation of the scaffold often leads to a sharp reduction in its mechanical properties, which limits the application of these biomaterials. As for H-CPP, a fast degradation results in a sharp reduction in the mechanical properties, while for PG-CPP, the density layer degradation slowly afford the mechanical property of the scaffold. Hence, as presented in Figure 3, the mechanical property of PG-CPP was significantly better than that of H-CPP.

In order to mimic a large segmental bone, some scaffolds with a radial gradient porosity were also prepared by using the same method as shown in Figure 4. The scaffold with a hollow center was $10 \mathrm{~mm}$ in diameter, and the diameter of the hollow center was about $4 \mathrm{~mm}$ (Fig. 4a). The porosity of the outer layer was $15 \%$ and could be adjusted by using different pore-forming agents. Scaffolds with two and three radial layers were presented in Figure $4 \mathrm{~b}$ and $4 \mathrm{c}$. Although the property of these scaffolds needed further proofs, we believe that these scaffolds with a radial gradient porosity could be useful in large segmental bone implants.

\section{CONCLUSION}

In this article, a porosity-graded calcium polyphosphate scaffold was prepared with the aim of simulating the bone tissue morphology. Porosity, porosity-graded structure, degradability and mechanical property of scaffolds were evaluated in vitro for bone implants. The results indicated that the porosity-graded scaffold showed a porosity percentage of $(32.73 \pm 0.71) \%$, with a pore size of about $200-400 \mu \mathrm{m}$ in diameter, and the porosity graded scaffolds are composed of an inner porous layer and outer compact CPP layers. In vitro degradation showed that the degradability of gradient scaffolds and homogeneous scaffolds did not have a significant difference due to the same porosity between them. The compressive strength test showed that the gradient porosity scaffold was better than the homogeneous scaffold regarding the degradation time. These findings may provide an approach to study and achieve a biomimetic scaffold with porosity gradients, as well as explore more biomedical applications.

\section{ACKNOWLEDGMENTS}

The authors are grateful to the NSFC for providing financial support through project 30870614. The author would also like to thank the professors in the Centre of Analysis and Testing of Sichuan University who provided the SEM measurement.

\section{RESUMO}

Um novo esqueleto mimetizando a morfologia de tecido ósseo e com uma estrutura de porosidade gradiente foi preparado e é descrito neste artigo. O resultado da avaliação da morfologia da superfície indicou que uma estrutura porosa gradiente se formou no esqueleto fabricado no qual uma camada densa $(0 \%)$ foi conectada com a camada mais porosa $(60 \%)$ por uma camada porosa média $(30 \%)$. Para avaliar a degradabilidade, esqueletos de porosidade gradiente e esqueletos homogêneos foram colocados em uma solução tampão Tris-HCL $(\mathrm{pH}=7,4)$ durante 28 dias. Observou-se que ambos os esqueletos apresentaram a mesma tendência de degradação e a estrutura de porosidade gradiente não modificou a degradabilidade original do esqueleto. Além disso, a força compressiva do esqueleto de porosidade gradiente foi melhor do que aquela do esqueleto homogêneo convencional, com aumento do tempo de degradação, e que a estrutura porosa em gradiente pode acentuar a propriedade mecânica do esqueleto. Estas observações sugerem que este esqueleto biodegradável de porosidade gradiente pode ser promissor para implantes ósseos.

Palavras-chave: biodegradavel, biomimético, esqueleto poroso gradiente, força compressora. 


\section{REFERENCES}

Athanasou N. 1996. Current Concepts Review - Cellular Biology of Bone - Resorbing Cells. J Bone Joint Surg 78: 1096.

BECKER B AND Bolton J. 1997. Corrosion behaviour and mechanical properties of functionally gradient materials developed for possible hard-tissue applications. J Mater Sci-Mater M 8: 793-797.

Castillo M, Moore J, Schowengerdt F, Ayers R, Zhang X, UMAKoshi M, Yi H AND GUIGNE J. 2003. Effects of gravity on combustion synthesis of functionally graded biomaterials. Adv Space Res 32: 265-270.

CHEN F, WANG K AND LIU C. 2008. Crystalline structure and its effects on the degradation of linear calcium polyphosphate bone substitute. Appl Surf Sci 255: 270-272.

DING Y, CHEN Y, QIN Y, SHI G, YU XAND WAN C. 2008. Effect of of polymerization degree of calcium polyphosphate on its microstructure and in vitro degradation performance. J Mater Sci-Mater M 19: 1291-1295.

Dion A, Langman M, Hall G and Filiaggi M. 2005. Vancomycin release behaviour from amorphous calcium polyphosphate matrices intended for osteomyelitis treatment. Biomaterials 26: 7276-7285.

El SaYegh T, Pilliar Rand McCulloch C. 2002.Attachment, spreading, and matrix formation by human gingival fibroblasts on porous-structured titanium alloy and calcium polyphosphate substrates. J Biomed Mater Res Part A 61: 482-492.

FISKE C AND SUBBAROW Y. 1925. The colorimetric determination of phosphorus. J Biol Chem 66: 375.

Grynpas M, Pilliar R, KANDEl R, RENLUnd R, Filiaggi M AND DUMitriU M. 2002. Porous calcium polyphosphate scaffolds for bone substitute applications in vivo studies. Biomaterials 23: 2063-2070.

HENCH L AND POLAK J. 2002. Third-generation biomedical materials. Science's STKE 295: 1014.

Hench LL. 1998. Bioceramics. J Am Ceram Soc 81: 1705-1728.

Hing K, Best S And Bonfield W. 1999. Characterization of porous hydroxyapatite. J Mater Sci-Mater M 10: $135-145$.

LIEBERMAN JR AND FrIEDLANDER GE. 2005. Humana Press, Totowa, New Jersey, Ch. 2 and Ch. 8.

PARK E, LeE Y, ChOI J, OH S, Shin H, KiM K, Kim SY AND KIM S. 2004. Cellular biocompatibility and stimulatory effects of calcium metaphosphate on osteoblastic differentiation of human bone marrow-derived stromal cells. Biomaterials 25: 3403-3411.

Pilliar R, Filiaggi M, Wells J, GrynPas M AND Kandel R. 2001. Porous calcium polyphosphate scaffolds for bone substitute applications - in vitro characterization. Biomaterials 22: 963-972.
Pompe W, Worch H, Epple M, Friess W, GelinsKy M, Greil P, Hempel U, Scharnweber D AND SChUlTe K. 2003. Functionally graded materials for biomedical applications* 1. Mater Sci Eng A 362: 40-60.

QIU K, WAN CX, CHEN X, ZHANG Q AND Su HF. 2005. In vitro degradation studies of calcium polyphosphate ceramics prepared by controlled degree of polymerization and crystallization. Asbm6: Advanced Biomaterials Vi 288289: 553-556.

QIU K, ZhaO X, Wan C, ZhaO C AND CHEN Y. 2006. Effect of strontium ions on the growth of ROS17/2.8 cells on porous calcium polyphosphate scaffolds. Biomaterials 27: $1277-1286$.

Song W, Tian M, Chen F, Tian Y, WAN C AND Yu X. 2008. The study on the degradation and mineralization mechanism of ion-doped calcium polyphosphate in vitro. J Biomed Mater Res Part B: Applied Biomaterials 89: 430-438.

Sous M, Bareille R, Rouais F, Clement D, Amedee J, DUPUY B AND BAQUEY C. 1998. Cellular biocompatibility and resistance to compression of macroporous [beta]tricalcium phosphate ceramics. Biomaterials 19: 2147-2153.

Tampieri A, Celotti G, Sprio S, Delcogliano A AND FRANZESE S. 2001. Porosity-graded hydroxyapatite ceramics to replace natural bone. Biomaterials 22: 1365-1370.

Waldman S, Grynpas M, Pilliar R AND Kandel R. 2002. Characterization of cartilagenous tissue formed on calcium polyphosphate substrates in vitro. J Biomed Mater Res (USA) 62: 323-330.

Wang Q, Wang J, Zhang X, Yu X AND Wan C. 2009. Degradation kinetics of calcium polyphosphate bioceramic: an experimental and theoretical study. Mater Res 12: 495-501.

WANG QB, WANG QG AND WAN CX. 2010a. The Effect of sintering time on the microstructure and properties of inorganic polyphosphate bioceramics. Science of Sintering 42(3): 337-343.

WANG QB, WANG QG AND WAN CX. 2011. The effect of porosity on the structure and properties of calcium polyphosphate bioceramics. Ceram-Silikaty 55(1): 43-48.

WANG QB, WANG QG, ZHANG XH, YU XX AND WAN CX. 2010B. The Effect of Sintering Temperature on the Structure and Degradability of Strontium-Doped Calcium Polyphosphate Bioceramics. Ceram-Silikaty 54: 97-102.

YANG SM, KIM SY, LEE SJ, LEE YK, LEE YM, KU Y, CHUNG CP, HAN SB AND RHYU IC. 2004. Tissue Response of Calcium Polyphosphate in Beagle Dog. Part II: 12 Month Result. Key Eng Mat, p. 245-248.

YOSHIKAWAHAND MYOUIA. 2005. Bonetissueengineering with porous hydroxyapatite ceramics. Journal of Artificial Organs 8: 131-136. 